\title{
Climate-Smart Cod
}

\begin{abstract}
We eat over 150 million fish \& chip meals each year in the UK. For fish and shellfish more generally, average consumption is now around 20 kilograms per person each year in the UK and US, but this is dwarfed by consumption in Asia-in China, it is nudging 35 kilograms per person a year for a population of over 1.3 billion. Cod remains the common source of British fish and chips, but stocks have experienced intense overfishing in the past and many have still not recovered. Warming in the North Sea has pushed Atlantic cod stocks further north, and most cod eaten in the UK now comes from Iceland and Norway. An uncooked cod fillet has a carbon footprint of around 300 grams. For a full portion of deep fried fish and chips, this rises to a kilogram of emissions. Cutting household wastage and improving the efficiency of cooking can reduce this. At sea, a switch from bottom trawling to pelagic fishing would reduce fuel use and also help to protect cod stocks and their food supplies on the ocean bed. For all fisheries, increased protection from overexploitation and pollution can lend them greater resilience in the face of climate change.
\end{abstract}

Keywords Fish \& chips $\bullet$ Shellfish $\bullet$ Bottom trawling $\bullet$ Sea ice $\bullet$ Grand Banks $\bullet$ North Sea $\bullet$ Iceland $\bullet$ Carbon footprint $\bullet$ Aquaculture

Chips are wonderful. A freshly battered piece of fish to go with them is nirvana. Fish \& chips remains a takeaway staple across the land, and each

(C) The Author(s) 2019

D. Reay, Climate-Smart Food, https://doi.org/10.1007/978-3-030-18206-9_13 
year, we wolf down over 150 million of these deep-fried delights [1]. Globally our appetite for fish and seafood continues to grow apace. In the US, Canada and the UK, there has been a steady increase in consumption since World War Two, and today, the annual average is about 20 kilograms of fish and shellfish per person. Across large parts of Asia, however, demand has exploded. In China, per capita consumption has grown more than eightfold since the 1960s and is now nudging 35 kilograms a year (Fig. 13.1). With a population of over 1.3 billion, that's an awful lot of fish.

Despite ballooning demand, the amounts of wild fish caught each year appear to be levelling off (at around 90 million tonnes a year). Filling the yawning supply gap has come aquaculture. From salmon farms to shrimp ponds, oyster rafts to carp pools, the marine and freshwater farming of fish and shellfish has become big business around the world. In 1960 it produced just 2 million tonnes of food globally. By 2015 it was topping 100 million tonnes a year and had comfortably overtaken wild capture as the main source of all things fishy in the world's food baskets [3].

Fish and seafood consumption per capita, 2013

Annual consumption of fish and seafood per person per year, measured in kilograms. Data is inclusive of all fish species and major seafood commodities, including crustaceans, cephalopods and other mollusc species. Data is

based on per capita food supply at the consumer level, but does not account for food waste at the consumer level.
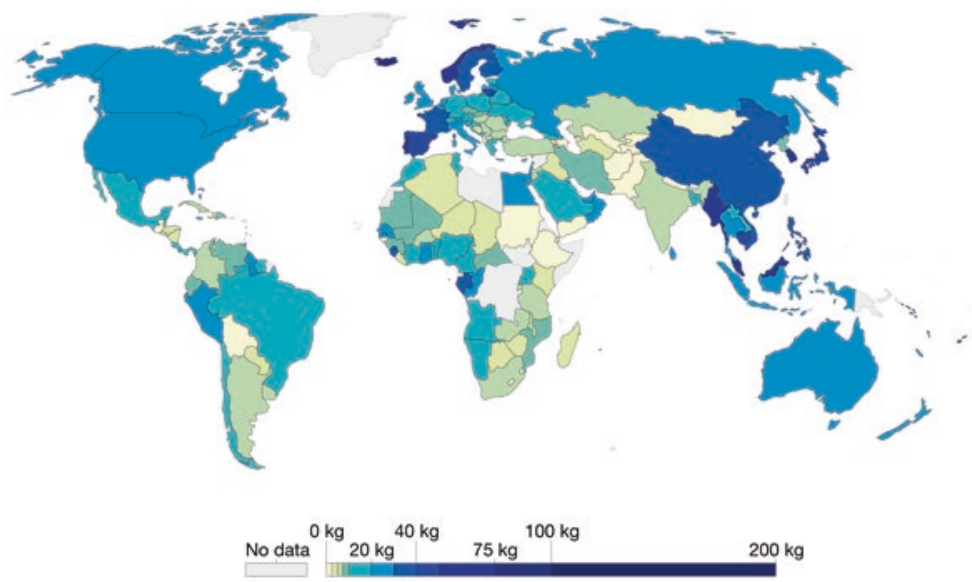

Fig. 13.1 Global fish and shellfish consumption per capita in 2013 (Source: Hannah Ritchie, Our World in Data) [2]. Available at: https://ourworldindata. org/grapher/fish-and-seafood-consumption-per-capita 
Here in Britain most fish \& chip suppers are still courtesy of wild catches of the wide-mouthed big-bellied fish that is the cod [4]. Cod has been a sought-after dinner for centuries and part of European diets since the stone age [5]. There are three main commercial species: the Atlantic cod (the source of our supper), the Pacific cod and the Greenland cod. They are slow swimmers, and their capacious maws mean they can hoover up everything from shrimp and other fish, to worms, shellfish and even sea urchins [6].

Atlantic cod inhabit surface waters right down to depths of more than 200 metres (sometimes as deep as 600 metres) and prefer water temperatures between 2 and 8 degrees Celsius. Females reach maturity at three to six years, and each produce several million eggs - the record from a single female is nine million-which are released over the ocean floor. The eggs hatch within about a month and, after a few more months as drifting larvae, the fry then settle down for a life mostly focussed on food gathering near the seabed. They can live for over 25 years [7]. Fish over 6 feet in length and weighing in at more than 200 pounds have been reported in the past, but such leviathans are likely long gone, and the average size of cod today is much diminished from its pre-twentieth-century heyday.

Like 90 per cent of the cod eaten in Britain, our own crisply battered cod fillets come from fish caught in the icy waters around Iceland and in the Barents Sea. There are still some cod closer to home, such as in the colder corners of the North Sea and off the northwest coast of Scotland [8], but the bulk of the supply for our 10,000 or so fish \& chip shops is now imported from Iceland and Norway [9].

To catch their quarry, trawlers use a range of techniques, including long lines that carry thousands of baited hooks attached at intervals along a buoyed main line up to 30 miles in length, and nets that either target fish in the middle or upper waters (pelagic) or those near the bottom (demersal) [10]. A traditional one for cod is the otter trawl, where cone-shaped nets are drawn across the sea bed with the net mouth kept open using rectangular steel boards - the otter boards - attached on either side [11]. Any cod in its path are directed into its funnel-like body and end up held in the aptly named 'cod end' at the back. Once hauled on board, the fish are usually gutted and covered with ice ready for the journey to shore. Back in ports like Reykjavík they are filleted and boxed up for refrigerated transport by sea to the deep-fat fryers of Britain.

Wild caught cod effectively have a carbon footprint of zero until they are caught, but after that the emissions can rapidly mount up. The catching phase is the big one. Fuel (usually diesel) is burned getting to and from 
the fishing grounds, as well as during trawling itself. Bottom trawls are especially fuel-intensive as the heavy net and otter boards need a lot of power to drag them along. The trawls can also catch many non-target species and have a devastating impact on the seabed ecosystems they plough through.

More energy use, and so emissions, arises from ice making, refrigeration and running the boats. For every tonne of edible cod, this catching phase results in the equivalent of over a tonne of carbon dioxide [12, 13]. Along with processing, onwards transport to the UK and still more refrigeration, each cod fillet arrives at the chip shop with a carbon footprint of around 300 grams [12]. As with chips, this is bumped up by the oil and energy then used for frying. The indispensable batter brings the life-cycle footprint of one crispy, deep-fried fillet to half a kilogram.

Our completed paper-wrapped bundle of battered fish fillet and generous portion of chips therefore tips the climate scales at about 1 kilogram. Rather weighty, but still a slim line climate supper compared to many of the plastic-encased meals on offer from our supermarkets-a ready-meal dinner of beef burritos, for example, has a carbon hoofprint five times that of our fish supper [14].

Given its takeaway nature, the options at home for us to directly cut the life-cycle emissions involved in fish \& chips appear limited. The packaging is rarely recyclable due to contamination by oil, and other than warming up plates in the anticipation of the meal's arrival, there isn't much home energy used in its consumption. As ever, where we can do most is in avoiding waste.

In the UK we throw away an estimated 35,000 tonnes of fish and shellfish each year. This includes guts, bones and shells, but over 80 per cent is deemed avoidable waste, due mainly to the food not being used in time or because too much is cooked or served [15]. It includes everything from tinned sardines and salmon steaks, to fish fingers and our battered cod fillets. Some products will have much lower carbon footprints than codfarmed mussels in Scotland are responsible for under 300 grams of emissions for each kilogram of shiny-shelled treats [16]. Others will be much more carbon-intensive. Spanish tuna, for instance, has a climate footprint of around 2 tonnes for every tonne of fish that gets to market [17]. Overall, the annual British wastage of these delicious fruits of the sea equates to around 30,000 tonnes of avoidable emissions. 
Over the centuries many fish species have had their share of trials and tribulations at the hands of humankind, but few can rival that of the Atlantic cod and its near-annihilation on Canada's Grand Banks. The Grand Banks are a group of shallow underwater shelves off the coast of Newfoundland that sit at the oceanic meeting point of the cold Labrador current and the warm Gulf Stream. The abundance of nutrients provided by these mixed-up waters makes for a super-productive sea and so a smorgasbord of crustaceans, worms and small fish. For centuries cod have been filling their boots.

In the 1600s fishermen reported that the cod shoals were so dense that they had trouble rowing through them [18]. Newfoundland's fishing industry grew fast as increasing numbers of boats came from Europe and Scandinavia to reap the seemingly endless catch. By the 1950s hulking factory trawlers, each able to catch and freeze many hundreds of tonnes of fish, were ploughing the rich waters for weeks at a time. Their frozen harvest was sailed back to ports all over the world, before the boats returned for another helping. The Grand Banks' cod stocks were massive, but even they could not withstand this industrial extermination. Each new year brought a new record catch, with 1968 seeing over 800,000 tonnes of fish taken. Those heights were never reached again. Despite bigger boats and nets, the catch began to slide. By the early 1970s it was down to 300,000 tonnes a year. The Canadian Government intervened. Not to protect the cod, but to extend the exclusive area over which it controlled fishing and so help its own fleet get in on the cod bounty.

Yet more factory trawlers and processing factories were built and a new homegrown pressure on stocks was ratcheted up. Scientific advice at the time was that a 250,000 tonne-a-year catch was sustainable. By the late 1980 s, that advice was found badly wanting. Catches nose-dived, yet fishing continued until there was virtually nothing left to catch. By the 1990s estimated cod stocks were just 1 per cent of their 1960s levels, and only 2,000 tonnes of breeding-age fish remained. The industry collapsed. Some 30,000 fishermen found themselves drawing benefits instead of nets, and another 15,000 in jobs like ship building and fish processing ended up out of work [18].

The disaster for people and cod alike that was the Grand Banks at least served as a warning to governments of the folly of setting politically motivated quotas. It was also a brutal wake-up call for fisheries science. Since then, evidenced-based policy and improved fisheries management have helped to head-off more catastrophic declines. Though sometimes 
only just. In 2006 the North Sea cod populations were rescued from the brink of collapse by a raft of measures such as larger mesh sizes in nets (to let younger fish escape), boat decommissioning and bans on fishing in nursery areas [9]. Today's stocks have recovered to a 35-year high (albeit from a desperately low baseline) but, just as a sustainable future for Britain's North Sea cod fishery appears within our grasp, climate change is snatching it away.

Temperature affects all the life-cycle stages of fish, including those of cod [19]. As oceans warm, so their reproductive success, food supplies, growth rates and distribution can be altered [20]. The effects vary depending on where the cod populations are. In the 1920s and 1930s, for instance, North Atlantic cod off the shores of West Greenland-the coldest northern reaches of their normal range-appeared to benefit from a warming sea. Down at their warmer southern limits, past warming has often been less welcome and numbers have declined [21, 22]. One key issue seems to be changing food supply as the waters warm and in particular the types and numbers of copepods (small, free-swimming crustaceans) and other zooplankton that the cod rely on in their early years. As water temperatures rose in the second half of the twentieth century, the distribution of cold-water copepods favoured by young North Sea cod retreated northwards [23].

In the twenty-first century, the North Sea, like most ocean areas, is set to warm a whole lot more. By the 2090s the average sea surface temperature could rise by a further 3 degrees Celsius (it is already about 1 degree Celsius warmer than in the 1960s $[24,25]$ ). This warming is projected to be most rapid in southern waters and during the summer months, when the seas become more stratified and a stable warm layer can form near the surface. Warming at depth will be slower, but the southern North Sea is shallow and its cod population faces the prospect of dwindling food supplies in waters that are becoming progressively warmer, less saline (due to ice melt and increased rainfall run-off), and more acidic (due to more carbon dioxide) [26].

Even without climate change, in the absence of sustainable fisheries management, North Sea cod stocks by the middle of the century are predicted to decline. With climate included, they would plummet. A moderate warming scenario suggests that the numbers of cod surviving long enough to join the adult population will drop by almost one-third. Under a rapid warming scenario, such cod recruitment in the North Sea could fall by over 95 per cent [27]—disaster on a grand (Banks) scale. 
North Sea cod ranges are already retreating to colder and deeper waters [28]. The picture for hundreds of other cold-water fish species around the world is a similar one of pole-ward retreat in the face of overheating oceans [29]. For some, populations at the chillier extremities of their species' range may benefit-warming of 1 to 2 degrees Celsius is expected to expand numbers of Atlantic cod around Greenland and in the iciest reaches of the Barents Sea $[19,30]$, while southern waters are becoming home to a host of new invaders, including sardines and cuttlefish, nosing up from the south [31].

For species like polar cod-a boreal cousin of the Atlantic cod but with a much lower and tighter preferred temperature range of -1 to 2 degrees Celsius-warming waters may deliver an extra whammy in the form of retreating sea ice and loss of the spring and summer nursery this ice provides for their larvae and fry [20].

Making plants and animals healthier in the first place is a fundamental step in building climate resilience. The same is true of our oceans. The ability of global fisheries and wider marine ecosystems to cope with the challenges of warming and acidification, of hurricanes and sea level rise, can be greatly increased by ensuring they are in the fittest state possible to do so. The future of coral reef systems, for instance, ultimately rests on whether we can keep warming to below 1.5 degrees Celsius by the end of the century, but in the meantime avoiding damage from issues like coastal run-off and eutrophication can at least lighten their load. For commercial fish species like cod, ensuring healthy populations through sustainable fisheries management-protecting breeding grounds and enforcing strict quotasis similarly vital if they are to weather the coming storm [30].

There's a risk that emissions from the cod trawler fleet will increase in the future as boats travel further and further from port to find fish [32]. Again, this risk could be reduced by boosting fisheries protection and so maintaining stocks closer to home. The boats themselves can cut emissions through improving engine efficiencies, using lower carbon fuels, and adopting alternative fishing methods. Switching away from the destructive and energy-intensive practice of bottom trawling is a prime example of this. By using different fishing methods, like drift netting and pelagic (upper water) trawls, the amount of fuel used per kilogram of fish caught can be cut by 80 per cent $[32,33]$. It also means less damage to seabed 
communities. As these provide much of the food cod and other commercial fish species rely on, their protection offers a longer-term triple-win of greater productivity of the fishery, lower emissions from the boats and enhanced climate change resilience of the wider ecosystem. The nets may have fewer cod when they are pulled on board, but in reality, the most climate-smart option for our future fish suppers may well be to embrace other fish species anyway.

Increasing numbers of restaurants and takeaways now offer alternatives like pollack, coley or hake as their battered dish of the day [34]. Warmerwater invaders like the red mullet and John Dory offer the prospect of new markets for the fishing fleets and new culinary delights for the dinner table [31]. Cod farming using seawater ponds or floating coastal pens may also help take some of the strain off wild populations. Though still a minor part of the global market, it is growing fast, with output in Norway having already increased to over 16,000 tonnes in 2008 [35]. In theory such managed production can avoid the large 'catch phase' emissions of wild stocks and give more resilience to climate change. Larvae and young fish can be reared under controlled conditions and the fish can be supplied with all the feed they need to grow fast [36].

With rearing ponds and cages being close to shore, however, warming risks may be even greater and concerns have been raised about farmed cod escaping (they are inquisitive fish and good at finding their way out of nets). Where these escapees interact with wild stocks, there is a risk of disease spread and of interbreeding that reduces the wild cod gene pool [35]. The low-carbon credentials of such cod aquaculture are also questionable as the emissions saved on the high seas are partially or wholly offset by those of producing the fish feed and of powering water pumps, filters and the rest.

Ultimately the climate-smart fillet in our fish supper will be one sourced from a system, whether wild or farmed, that takes full account of the impacts of a changing climate. It will also be one that strives to limit its own role in accelerating those impacts. Wild fisheries and aquaculture directly employ over 50 million people around the world, with a tenth of the global population deriving their livelihoods in one way or another from fish and shellfish. Nine out of ten people working in capture fisheries are in small-scale artisanal operations. Providing them with good support and advice, alongside sustainable finance and evidence-based regulation, can help ensure that our growing reliance on fish and shellfish for global food security is climate-proofed [37]. 


\section{REFERENCES}

1. Federationoffishfriers.co.uk. Fish and Chips, Facts and Figures. http://www. federationoffishfriers.co.uk/pages/facts-and-figures-603.htm (2019).

2. Ritchie, H. Global fish and shellfish consumption per capita, 2013. Ourworldindata.org. https://ourworldindata.org/grapher/fish-and-seafood-consumption-per-capita (2018).

3. Ritchie, H. Global production from capture fisheries versus from aquaculture, 1960-2015. Ourworldindata.org. https://ourworldindata.org/grapher/ capture-fisheries-vs-aquaculture-farmed-fish-production (2018).

4. SeaFish. The Fish We Eat With Our Chips-The Facts. https://www.seafish. org $/$ media $/ 390797 /$ the fish we eat with our chips - the facts - master jan 2011.pdf (2018).

5. msc.org. What is Cod? https://www.msc.org/what-you-can-do/eat-sustainable-seafood/fish-to-eat/cod (2019).

6. Kennedy, J. Atlantic Cod (Gadus morhua). thoughtco.com. https://www. thoughtco.com/atlantic-cod-gadus-morhua-2291590 (2017).

7. UCD.ie. Cod Biology. http://www.ucd.ie/codtrace/codbio.htm (2002).

8. seafoodscotland.org. Responsible Sourcing-Cod. http://www.seafoodscotland.org/ja/responsible-sourcing/top-species/cod.html - biology (2019).

9. Carrington, D. Sustainable British Cod on the Menu After Stocks Recover. The Guardian. https://www.theguardian.com/environment/2017/jul/19/ sustainable-british-cod-on-the-menu-after-stocks-recover (2017).

10. britishseafishing.co.uk. Commercial Fishing Methods. http://britishseafishing. co.uk/commercial-fishing-methods/ (2019).

11. mcsuk.org. How Fish are Canght. https://www.mcsuk.org/media/seafood/ Fishing_Methods.pdf (2019).

12. Smárason, B., Viðarsson, J., Thordarson, G. \& Magnúsdóttir, L. Life Cycle Assessment of Fresh Icelandic Cod loins (Reykjavík: Matís, 2014).

13. Sund, V. Environmental Assessment of Northeast Arctic Cod Caught by LongLines and Alaska Pollock Caught by Pelagic Trawls (SIK Institutet för livsmedel och bioteknik, 2009).

14. Tesco. Product Carbon Footprint Summary. https://www.tescoplc.com/ assets/files/cms/Tesco_Product_Carbon_Footprints_Summary(1).pdf (2012).

15. WRAP. Household food and drink waste in the United Kingdom 2012. Waste and Resource Action Programme. http://www.wrap.org.uk/sites/files/wrap/ hhfdw-2012-main.pdf.pdf (2013).

16. Fry, J. M. Carbon Footprint of Scottish Suspended Mussels and Intertidal Oysters. Scottish Aquaculture Research Forum (SARF). http://www.sarf.org.uk/cmsassets/documents/43896-326804.sarf078 (2012). 
17. Hospido, A. \& Tyedmers, P. Life cycle environmental impacts of Spanish tuna fisheries. Fish. Res. 76, 174-186 (2005).

18. britishseafishing.co.uk. The Collapse of the Grand Banks Cod Fishery. http:// britishseafishing.co.uk/the-collapse-of-the-grand-banks-cod-fishery/ (2019).

19. Drinkwater, K. F. The response of Atlantic cod (Gadus morhua) to future climate change. ICES J. Mar. Sci. 62, 1327-1337 (2005).

20. Dahlke, F. T. et al. Northern cod species face spawning habitat losses if global warming exceeds $1.5^{\circ}$ C. Sci. Adv. 4, eaas8821 (2018).

21. Mieszkowska, N., Sims, D. \& Hawkins, S. Fishing, Climate Change and North-East Atlantic Cod Stocks (2007).

22. O’brien, C. M., Fox, C. J., Planque, B. \& Casey, J. Fisheries: Climate variability and North Sea cod. Nature 404, 142 (2000).

23. Beaugrand, G., Brander, K. M., Lindley, J. A., Souissi, S. \& Reid, P. C. Plankton effect on cod recruitment in the North Sea. Nature 426, 661 (2003).

24. Wiltshire, K. H. \& Manly, B. F. The warming trend at Helgoland Roads, North Sea: Phytoplankton response. Helgol. Mar. Res. 58, 269 (2004).

25. Carbonbrief. Mapped: How every part of the world has warmed-And could continue to warm. Carbonbrief.org. https://www.carbonbrief.org/mappedhow-every-part-of-the-world-has-warmed-and-could-continue-to-warm (2018).

26. Schrum, C. et al. North Sea Region Climate Change Assessment 175-217 (Springer, 2016).

27. Clark, R. A., Fox, C. J., Viner, D. \& Livermore, M. North Sea cod and climate change-modelling the effects of temperature on population dynamics. Glob. Chang. Biol. 9, 1669-1680 (2003).

28. Engelhard, G. H., Righton, D. A. \& Pinnegar, J. K. Climate change and fishing: A century of shifting distribution in North Sea cod. Glob. Chang. Biol. 20, 2473-2483 (2014).

29. Morley, J. W. et al. Projecting shifts in thermal habitat for 686 species on the North American continental shelf. PLoS One 13, e0196127 (2018).

30. Kjesbu, O. S. et al. Synergies between climate and management for Atlantic cod fisheries at high latitudes. Proc. Natl. Acad. Sci. 111, 3478-3483 (2014).

31. McKie, R. Cod and haddock go north due to warming UK seas, as foreign fish arrive. The Observer. https://www.theguardian.com/environment/2017/ sep/02/fish-conservation-foreign-species-uk-waters-climate-change (2017).

32. EC. The carbon footprint of fisheries. Seas at Risk. European Commission. https://energyefficiency-fisheries.jrc.ec.europa.eu/c/document_library/ get_file? uuid=924clba8-94af-440d-94cb-f9cbl24d2d57\&groupId=12762 (2009).

33. Ziegler, F. \& Hansson, P.-A. Emissions from fuel combustion in Swedish cod fishery. J. Clean. Prod. 11, 303-314 (2003). 
34. McDonald, K. Sustainable seafood: How to eat fish without destroying the ocean. iNews. https://inews.co.uk/news/uk/sustainable-seafood-eat-fishdestroying-ocean-cod-king-prawn-replacement/ (2018).

35. Fouché, G. Rapid growth in European cod farming prompts fears from green groups. The Guardian. https://www.theguardian.com/environment/2009/ jun/22/european-cod-farming-norway (2009).

36. thefishsite.com. How to Farm Atlantic Cod. https://thefishsite.com/articles/ cultured-aquatic-species-atlantic-cod (2012).

37. FAO. Climate-Smart Fisheries and Aquaculture. Food and Agriculture Organization of the United Nations. http://www.fao.org/climate-smartagriculture-sourcebook/production-resources/module-b4-fisheries / b4-overview/en/ (2017).

Open Access This chapter is licensed under the terms of the Creative Commons Attribution 4.0 International License (http://creativecommons.org/licenses/ by $/ 4.0 /$ ), which permits use, sharing, adaptation, distribution and reproduction in any medium or format, as long as you give appropriate credit to the original author(s) and the source, provide a link to the Creative Commons licence and indicate if changes were made.

The images or other third party material in this chapter are included in the chapter's Creative Commons licence, unless indicated otherwise in a credit line to the material. If material is not included in the chapter's Creative Commons licence and your intended use is not permitted by statutory regulation or exceeds the permitted use, you will need to obtain permission directly from the copyright holder.

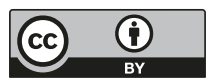

